\title{
ANTIQUITY
}

One final point: how were these openings made? Clearly, they were not sawn or drilled and there are no stray cut marks to suggest that the bone was pared away with a free knife edge. Nothing is more remarkable about them, as a group, than the regularity of the grooves in which these openings lie. The transverse diameters of all six grooves, across the bevel, fall within the limits of $22.5 \pm \mathbf{r} .5 \mathrm{~mm}$., a quite astonishingly narrow range. As one who has done trephinations (albeit by a different technique) I am prepared to suggest that this not only indicates that each operation was done by the same surgeon but also that each was done with the same instrument. It is known that Anglo-Saxons had gouges and these would be excellent instruments for performing trephinations. After our anonymous surgeon had incised the scalp and exposed the periosteum he could use his gouge to remove slivers of bone, from an ever deepening channel, probably gliding it to and fro from alternate ends as the operation progressed, and controlling the final opening into the cranial cavity according to his assessment of the situation. I envisage a gouge about $18 \mathrm{~mm}$. wide and having an arc of approximately a third of a circle. Allowing for some slight 'play' in use, this has been found, experimentally, to produce grooves and bevels of the pattern common to all these skulls.

When art historians identify a distinguished but nameless early painter, from some particularity of his work, they have the gracious custom of rescuing him from total anonymity by devising a well-chosen sobriquet. It is thus that we have come to know the Master of the Mousetrap or the Master of the Female Half Length. Dare I, too, rescue an early colleague from oblivion and introduce a great AngloSaxon surgeon as the Master of the Gliding Gouge?

CALVIN WELLS

Acknowledgements: My thanks are due to Francis Cheetham, Esq., Director, Norwich Museums; to A. R. Edwardson, Esq., Hon. Curator, Moyse's Hall Museum, Bury St Edmunds; to Miss A. S. Mottram, Curator, King's Lynn Museum; and to Dr Peter Wade-Martins, who have allowed me to publish one or other of these specimens. Also to Miss E. B. Green, B.Sc., FSA, for her most helpful discussions and advice about these skulls.

GIOT, P. R. I949. Les trépanations de la nécropole gauloise de Saint-Urnel en Plomeur, Bull. Mém. Soc. Anthrop., x, 59-69.

WEBSTER, L. E. and J. CHERRY. 1972. Medieval Britain in 1971, Med. Archaeol., xvi, I57.

Wells, CalviN. 1964. Bones, bodies and disease (London).

1966. Report on the human remains, in $P$. Hutchinson, The Anglo-Saxon cemetery at Little Eriswell, Suffolk, Proc. Camb. Ant. Soc., LIX, I-32.

WILsON, D. M. and D. G. HURST. I 970. Medieval Britain in $1969, \mathrm{Med}$. Archaeol., XIV, I6I.

WILSON, D. M. and S. MOORHOUSE. I97I. Medieval Britain in 1970, Med. Archaeol., xv, I30.

\section{Lapita pottery at Talasea, West New Britain, Papua New Guinea}

fim Specht is Assistant Curator of Anthropology in the Australian Museum, Sydney. The Lapita style pottery has been the dominating element in Oceanic prehistory for the last two decades. The distances over which pottery and obsidian travelled in Melanesia are clearly staggering by European terms, and European archaeologists should be aware of them. We welcome this contribution from Papua New Guinea.

Lapita pottery, in its classic decorated form dated between 3200 and 2500 years BP, has acquired considerable importance through its apparent connexion with the ancestors of the Polynesian peoples (Poulsen, 1968; Golson, I97I; Groube, 197I; Green, 1973). This note records the discovery of this pottery at one of the most important obsidian sources in the western Pacific, Talasea on the north coast of New Britain, Papua New Guinea. Several sites in island Melanesia have yielded flakes of obsidian identified, by trace element analysis, as originating from the Talasea source (Key, 1968; Ambrose and Green, 1972). At some of these sites, such as those on Watom and Ambitle Islands in the New Guinea region (Specht, 1967; 1968; White and Specht, 1971), this obsidian is the only material from which flaked stone tools were made. The widespread dispersal of Lapita sites across 4,000-plus $\mathrm{km}$. of ocean, and the persistent occurrence of 


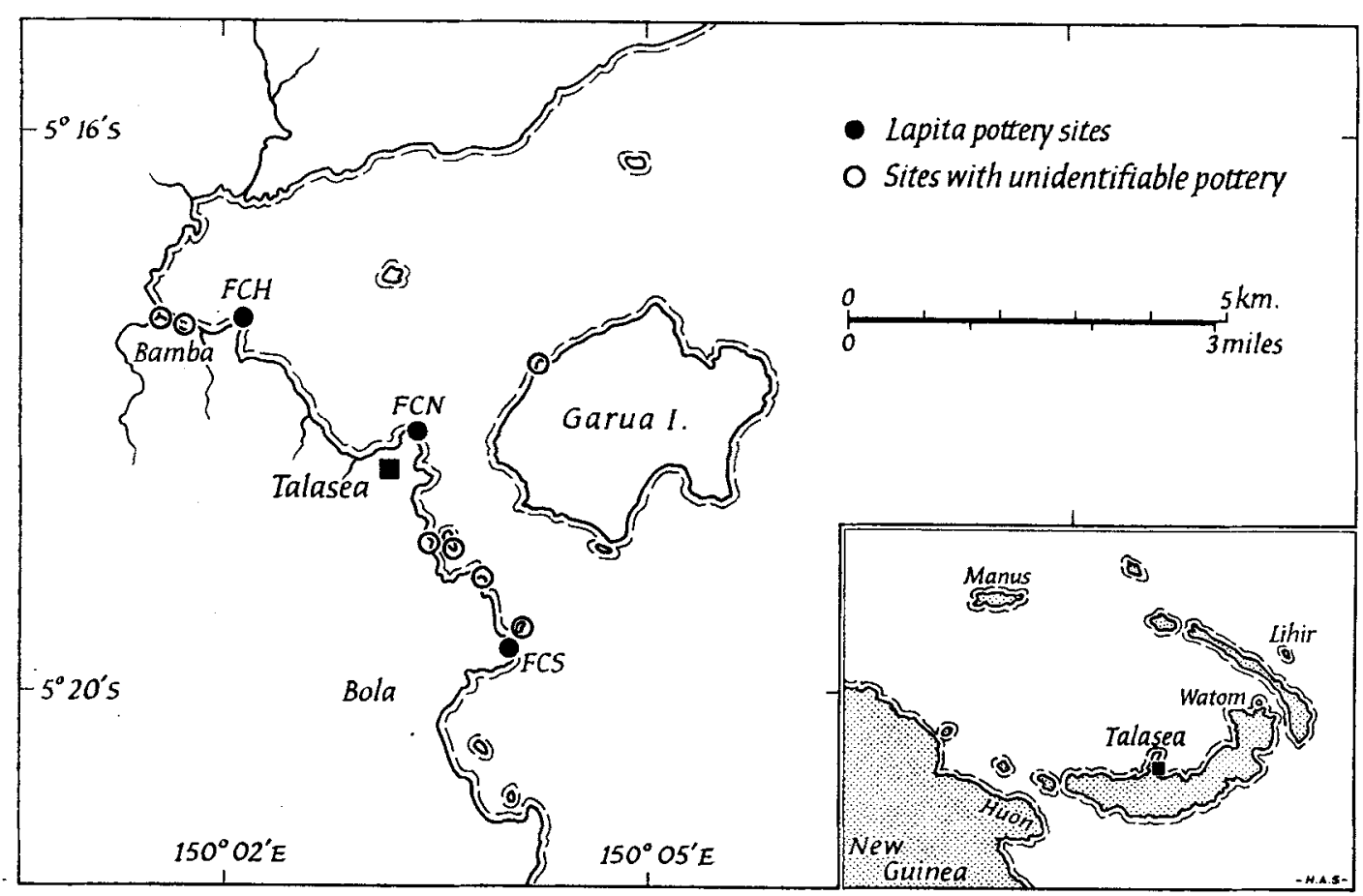

Fig. I. Map of the Talased area, West New Britain, showing locations of main sites found in 1973

imported raw materials, such as metamorphic and ultrabasic rocks in addition to obsidian, have led Green (1973) to depict the Lapita pottery makers/users as having played an important rôle in the earliest trading networks yet reported from island Melanesia.

In May 1973 I visited Talasea to investigate a site discovered in 1972 by J. Kamminga on Rala Bay, Bamba village, about $3 \mathrm{~km}$. west of Talasea Government Station (FIG. I). This site, code $\mathrm{FCH}$, is located on a volcanic sand beach near an exposed obsidian flow. It is a workshop site with dense concentrations of waste flakes and finished artifacts scattered over $800 \mathrm{~m}$. of beach between the present high and low tide levels. Some of the finished tools resemble those previously reported from Talasea, Manus and Lihir Island (Casey, 1939). In 1973 a single sherd of Lapita pottery was found about $100 \mathrm{~m}$. east of this site, on a mudflat that is exposed at low tide (FIG. 2).

The most important finds of Lapita pottery were made at site FCS on Chobu Beach, near
Bola village, about $4 \mathrm{~km}$. east of the Station. This site stands on one of the few sections of raised coral reef to be found near Talasea, which is predominantly of volcanic origin. Plain and decorated sherds, obsidian flakes and fragments of ground axe/adzes were found at high tide level, where the sea is eroding the beach front (FIG. 3). Artifacts were also found on the ground surface above the beach over a distance of approximately $800 \mathrm{~m}$. The ground stone tools are made from a pale green sedimentary rock foreign to Talasea; though clearly imported, its source is, as yet, not known.

The full extent and nature of this site may never be known. It has been almost totally destroyed by bulldozers excavating for 'koronas', a crushed coral road surfacing material. The bulldozers have removed the volcanic ash topsoil and the underlying calcareous sand in which the Lapita site is thought to have been located. Examination of the site suggests that little, if any, of the original deposit remains in situ. 


\section{ANTIQUITY}

A third find of Lapita pottery was made on the beach of Mondu Point, just east of the Station wharf. Here heavily weathered sherds and a ground stone tanged implement made from the pale green rock were found at high tide level (FIG. 4). This site, FCN, is also situated on an emerged coral platform with calcareous beach sand. Once again bulldozers have disturbed the deposit, the extent of which cannot now be determined.

Petrographic and stylistic analysis of these finds is proceeding and should help to clarify the age and source of this Lapita pottery. The pottery was probably traded into the area, perhaps as a trade item against obsidian ( $c f$. Groube, 1971; Specht, 1972; Green, 1973). In recent times the present inhabitants of Watom Island sailed directly to Talasea to obtain obsidian, and similar direct voyages may have been made by the Lapita pottery makers. However, the transport of Talasea obsidian to the southern Solomon Islands, some 2,000 km. to the south, is more likely to have been through a series of group-to-group exchanges. It is also possible that the obsidian found by Green formed part of the original cargo of the Lapita settlers in the Solomons.

An important question requiring further examination is the relationship between the obsidian workshop site FCH and the Lapita pottery sites of Talasea. Although very close to Talasea, site FCS lies outside the limits of the obsidian flows, and informants from nearby Bola village stated they used to obtain obsidian through trade with more favourably located villages such as Bamba. This situation must also have obtained at the time of the Lapita settlement at FCS. Several fragments of obsidian implements similar to those found at site $\mathrm{FCH}$ were picked up among the sherds at site FCS, possibly indicating that they were contemporary with the Lapita pottery occupation. The single Lapita sherd from the workshop site was an isolated find, and the few sherds found among the obsidian scatters there are of indeterminate age and origin.

In 1972 Kamminga and I conducted an intensive site survey along $60 \mathrm{~km}$. of the north coast of the Huon Peninsula of New Guinea, an area which figures prominently in Harding's (1967) study of trade across the Vitiaz Strait. This survey did not locate any sites with Lapita pottery or obsidian tools similar to those from site FCH. This absence of Lapita pottery is of interest since, with the exception of one sherd reputedly found near Aitape many years ago (G. Pretty, South Australian Museum: pers. comm.), Lapita pottery sites do not occur on the New Guinea mainland. Allen (1972a; $1972 \mathrm{~b})$ has drawn attention to a possible relationship between Lapita and his red-slipped ware of the Papuan south coast, but the classic Lapita pottery still retains its essentially oceanic distribution. The absence of the $\mathrm{FCH}$ style of obsidian artifacts may also be significant, since in recent times Talasea obsidian was an important trade item entering the Huon Peninsula (Harding, 1967). While this absence may imply that the complex trading system described by Harding is of more recent origin than either Lapita pottery or the FCH site, it must be noted that, in this recent trade, obsidian was transported in the form of unprepared cores and not as finished artifacts.

Acknowledgements: The author's fieldwork was supported by the Australian Museum, Sydney. Kamminga's work in 1972 was financed by the Ian Potter Foundation, Melbourne.

Allen, J. r972a. Nebira 4: An early Austronesian site in Central Papua, Archaeology and Physical Anthropology in Oceania, vII, 92-124.

1972b. The first decade in New Guinea archaeology, Antiquity, xLVI, I80-90.

AMBROSE, W. R. and R. C. GRERN. 1972. First millennium BC transport of obsidian from New Britain to the Solomon Islands, Nature, $237,3 \mathrm{I}$.

CASEY, D. A. 1939. Some prehistoric artifacts from the Territory of New Guinea, National Museum of Victoria, Memoirs, XI, I43-50.

GoLsoN, J. I 97I. Lapita ware and its transformations, in (eds.) R. C. Green and M. Kelly, Studies in Oceanic culture history, Vol. 2, 67-76. Pacific Anthropological Records no. I2, Bishop Museum, Honolulu.

GREEN, R. C. I973. Lapita pottery and the origins of Polynesian culture, Australian Natural History, XVII, 332-7.

GROUBE, L. M. I97I. Tonga, Lapita pottery and Polynesian origins, Yournal of the Polynesian Society, LXXx, 278-316.

HARDING, T. G. 1967. Voyagers of the Vitiaz Strait (Seattle). 


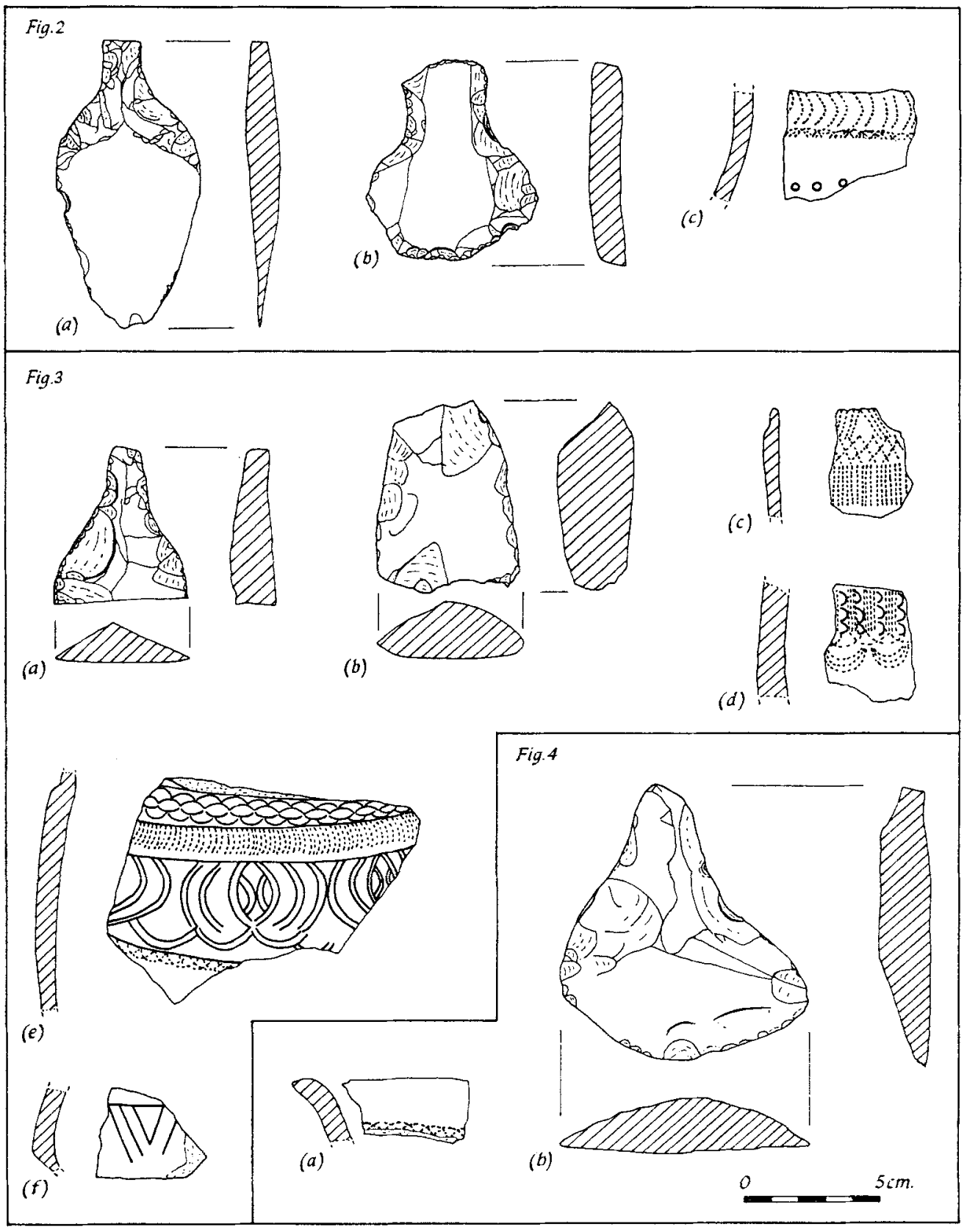

Fig. 2. Surface finds from site FCH. $2 a, 2 b$ : tanged obsidian artifacts; $2 c$ : sherd of Lapita pottery. Fig. 3. Surface finds from site FCS. $3 a:$ fragment of tanged obsidian artifact; $3 b:$ damaged ground stone adze blade; $3 c, 3 d, 3 e:$ sherds of Lapita pottery; $3 f:$ sherd with incised motif. Fig. 4 . Surface finds from site FCN. 4a: flaked and ground stone adze blade; $4 b:$ sherd of Lapita pottery 


\section{ANTIQUITY}

KEY, C. A. 1968. Trace element identification of the source of obsidian in an archaeological site in New Guinea, Nature, 2r9, 360.

pOULSEN, J. 1968. Archaeological excavations on Tongatapu in (eds.) I. Yawata and $Y$. $H$. Sinoto, Prehistoric Culture in Oceania, 85-92. (Honolulu).

SPECHT, J. 1967. A prehistoric pottery site in coastal New Guinea, Antiquity, XLI, 229-30.
1968. Preliminary report of excavations on Watom Island, TPNG, Fournal of the Polynesian Society, LxxvII, I I7-34.

1972. Evidence for early trade in Northern Melanesia, Mankind, virl, 310-r2.

White, J. P. and J. SPECHT. I97 I. Prehistoric pottery from Ambitle Island, Bismarck Archipelago, Asian Perspectives, XIv, 88-94.

\section{Nottingham Hill, Gloucestershire, 1972}

This is an interim report by Michael Hall (Part I), and Christopher Gingell (Part II), on their September 1972 excavation on Nottingham Hill in the NW Cotswolds, where, within the defences of a hillfort, they had the rare opportunity of examining an undisturbed Late Bronze Age hoard, apparently deposited on an occupation surface. The hoard itself is now the subject of detailed technical examination, but we are glad to give our readers (albeit later than we had hoped owing to pressure on space) this summary advance statement. $\mathrm{Mr}$ Hall is Archaeological Field Officer for the Thames Conservancy, and $\mathrm{Mr}$ Gingell Field Archaeologist (Rural) for Wiltshire based on Devizes Museum; the drawings are by his wife, Mrs fosephine Gingell.

I THE EXCavations: Nottingham Hill is a bivallate hillfort of 49 ha. (I 20 acres), in the Gloucestershire parish of Gotherington (SO9828). It is the largest of the Cotswold forts, although, as FIG. I demonstrates, the defences and entrances have been severely mauled by quarrying. No formal excavations have been undertaken previously on the site, though various ambiguous references in county histories testify to stray Romano-British finds from Nottingham Hill. No such material has survived.

The ploughing up of two intact Ewart Park-type swords in 1972 was reported by the contractor, $\mathrm{Mr}$ Terry Lishman, to the landowner, Mr David Abbatt, who in turn informed Cheltenham Museum. Mr Abbatt's willingness to allow fuller investigation was welcomed by the Museum, who, in conjunction with the Gloucestershire College of Art and Design, instructed C. J. Gingell and M. R. L.
Hall to undertake discreet and selective excavations. These took place after the harvest in September 1972.

Prior to any trenching, Dr Martin Aitken, of the Research Laboratory for Archaeology, Oxford, surveyed the area around the original findspot, with both proton magnetometer and metal detector. Regrettably, the area examined was too small to provide significant results supported by the magnetometer survey. Excavation in conjunction with the metal detector survey was, however, productive and economical. A total area of $122.5 \mathrm{sq}$. $\mathrm{m}$. was examined, within Dr Aitken's original grid.

Tentatively, it is possible to demonstrate two periods of activity on this part of the site. The earliest is represented by a markedly worn 'track', running from north-west to south-east, along the longer axis of the fort. Trial-trenching confirmed the abraded nature of the oolite on this axis; a shelving depression in the ground, either side of the excavated grid, offers some hint of continuity.

Subsequent activity is represented by the remains of a hearth, in the middle of the track alignment. Five sub-circular soil-filled features were recorded, in the rougher oolite either side of the 'track', but it was thought irresponsible to excavate these at this time. Their destruction would indeed have added little valuable information to this limited exploration.

About 150 sherds of pottery were found, with their greatest concentration in the area enclosed by the unexcavated features. The pottery is much damaged by the plough, but displays a characteristic dark brown paste, tempered with limestone grits. Two sherds bear incised decoration, one of them a rudimentary 